\title{
The Representation of British Foreign Policy
}

The English are divided in two categories, clearly identified by those who study zoology: the first one is represented by that famous Englishman who was marvelled not to find negroes in Calais, for, according to him, the Channel was the border of the civilised world. The second category is the one of types like Hervey, who [.. .] being in the Venetian Lagoon, tasted the water and concluded 'it is salty, hence it is ours!'

What in the world is this famous English friendship? We want to see the proof! ${ }^{2}$

Despite the most-imbecilic British gruffness of Lord Curzon, I am proud to be that famous 'irresponsible adventurer' that nobody dares to punish. ${ }^{3}$

T N MARCH 1922, MORE than half a year before the March on Rome that would start twenty years of Fascist rule in Italy, Margherita Sarfatti published an article about Rudyard Kipling in the Fascist intellectual magazine Gerarchia. Sarfatti was born to a Jewish family in Venice in I880. Her ancestry would

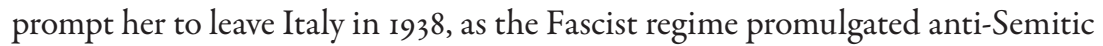
legislation. She was to return to Italy only in 1947, after the Second World War and the end of Fascism. All this was still far in the future in 1922. Sarfatti was a writer, art critic and overall renowned intellectual. She was also the lover of renegade Socialist and current leader of the Fascist party, Benito Mussolini. The article analysed the famous British writer as one universal archetype. Rather than being simply a nationalist or imperialist writer, Sarfatti wrote, Kipling was 'the singer of the will of domination and expansion not just of Britannismo, [Britishness] but of the West in general.' At the same time, however, he also represented 
what was best of Anglo-Saxoness, that the Italian people, like other Latins, should better learn to survive in the tired world that emerged from the Great War:

From one side to the other of Anglo-Saxon art [. . .] act! Work! [These] are the code words [that] ring like a trumpet call. [. . . Mowgli [...] man amongst beasts; Kim, sahib, white man amongst Indians; Kipling, man, amongst the soft feminine seductions of regret and sterile torment [...] they are three acts of overcoming and three victories; three gradual steps of Man who affirms himself, appealing from the crepuscular regions of subconscious, to the clear and firm rule of reason. ${ }^{4}$

'England,' she continued, 'is a country of extreme morality - also because it owns colonies.' 5 Sarfatti then drew a comparison between Britain and Ancient Rome, specifically late Republican Rome, having to reconcile its new imperial dominion over a vast and diverse world with its austere traditions. 'Such was the crisis of England after the death of the old Queen [Victoria] who turned the Kingdom into (or at least under her it was turned into) an Empire.' Yet while Britain had retained its respectable and 'feminine' values in the motherland, its men went to the rest of the Empire in order to express their conquering vital instincts, so that the home country was mostly inhabited by women and children. In the Empire, confronted with countless petty gods and diverse cultures, these men expanded the Christian, respectable education they had received at home 'on their mothers lap.' In this way, the British man 'greatly expands the horizon of the divine that [he] finds in himself.'

At the base of this relative irreligiosity and amorality stands a great faith and an absolute unique moral. The unassailable dogma of self-control, which admits no scepticism, the [.. .] ideal of the man-gentleman able to dominate himself, and who has conquered his own passions is stronger, as the Bible says, than he who has conquered cities. Once again, like in Rome, it is the warrior ideal of virtue?

Sarfatti's mention of Rome was not casual, or negligible, as the importance of the Roman myth in Fascist rhetoric can hardly be overestimated. During the Fascist era, Ancient Rome would continuously be celebrated in order to give historical substance to the imperial destiny of the Italian people. References abounded to the solemn greatness of its monuments and Rome was feted as an ideal of martial spirit, good governance and patriotism, which the Fascists sought to emulate. ${ }^{8}$ Furthermore, the description of the British as virile, conquering and always in control of themselves and of the world, shows striking 
resemblance with what was soon to be another myth of Fascism: the one of the New Fascist Man. This concept, as Emilio Gentile explained,

combined the ideas of Nietzsche, Pareto, Le Bon, Sorel, of the critics of science and of the prophets of the sunset of the West: the philosophy of life triumphant after the process of destruction of reason at the hands of reason itself. ${ }^{9}$

This New Man had to be able to 'conquer himself spiritually' and to reach, through the control of his instincts and passions, a new moral and spiritual vigour: that triumph was key to any other military, political, cultural and social success. ${ }^{10}$ The importance of the New Man's masculinity as understood by the Fascists also has echoes in Sarfatti's words. As Lorenzo Benadusi underlined, during the Fascist era 'a new idea of masculinity takes shape as a point of comparison to its effeminate counterparts, helping to define, through a negative opposition, the attributes of an ideal type model.' ${ }^{\text {'1 }}$ Sarfatti contrasts the Englishman's hard, vital and controlled 'conquering' virility with the femininity of the wives and children living in the respectable motherland, as well as with that of the 'conquered' peoples of the colonies. This, and the comparison with Rome, hinted not too subtly that, if not the British nation as a whole, British men were an example the new Italian people had to follow.

Although this appraisal of the greatness of Britain was unrepresentative of the views voiced by most of the Fascist elite in the years that followed, the comparison with Rome resurfaced during the Second World War. In September 1943, Giuseppe Bottai wrote in his diary about Britain and the possible comparisons between ancient and modern nations. Bottai was a journalist, a prominent Fascist intellectual and politician, and had at times enjoyed Mussolini's favour. He supported both the alliance with Nazi Germany and the anti-Semitic legislation. After falling from his master's grace and witnessing the catastrophe of the Fascist war, Bottai became increasingly critical of the Duce's decisions - at least in his own diary. He went from words to actions on 25 July 1943, when he voted for Dino Grandi's motion to depose Mussolini. After 8 September 1943 and the German occupation of parts of the country, Bottai had to hide in order to avoid being put on trial for treason. During his days in hiding, he devoted much time to his diary, writing reflections on the fallen regime, the war and many other topics. On 27 September 1943, hiding in a convent from the same Germans with whom he had long championed an alliance, Bottai reflected on Titus Livius' account of the Second Punic War. The reading suggested to him a comparison between the ancient war and the current one. The war had shown, Bottai thought, the fallacy 
of the notion, introduced by Mussolini, that Britain was the modern Carthage. 'If anything $[\ldots]$ it is more true that England is the modern Rome. ${ }^{12}$ Bottai's comparison was drawn from the British behaviour during the war. Like Republican Rome, London had managed to endure initial terrible defeats, refusing to even consider surrendering and flatly rejecting any peace proposal by the German side. Eventually, Britain managed to turn the tide of the conflict.

Sarfatti and Bottai's biographies have points in common. Neither managed to remain close to Mussolini until the end, but both enjoyed periods of remarkable confidence and influence on the Duce and came to know him well enough. Furthermore, both contributed to laying the cultural bases for the Fascist regime: Sarfatti edited Gerarchia and Bottai founded and edited Critica Fascista, two influential, elite Fascist magazines. The two pieces were written at the beginning and end of the Fascist era, respectively, while both compared Britain positively with one of the pillars of the Fascist imaginary. Yet, as Bottai hints in his diary, the identification of Britain, not with Rome but rather her mortal rival Carthage, was introduced by Mussolini and found fertile ground in the country - so much that an echo of it survives to this day. How did London shift from being identified with the exalted Rome to being the disdained Carthage?

Gerwin Strobl's study of the German perception of British foreign policy and the British Empire during the Weimar Republic (1918-1933) and the Third Reich (1933-1945) suggests that widespread admiration for both existed among the German population, particularly among scholars of English language and culture. Britain was seen as a nation that was both culturally and racially close to, and yet more successful than, Germany. Nazi leaders considered British foreign policy (so often ruthless and brutal) as well as the British sense of superiority (subtly but surely racially motivated) good examples to follow. At the time of Adolf Hitler's diplomatic triumphs, Britain's past was used as a shield against accusations of national egoism: for example, Britain's purely nationalistic, bold attitude during the Fashoda Incident with France in 1898 was mentioned by German commentators during the reoccupation of Rhineland in 1936. London was also held up as a model to replicate within the new Nazi central European empire; the installation in 1939 of a German protectorate in the western part of the former Czechoslovakia was modelled on Britain's domination of its Indian subjects. It was only after the beginning of the Second World War that the atrocities of the British Empire started to be used as propaganda, and with little success. ${ }^{13}$

What picture can be drawn of the Italian Fascist perception of Britain as an international player? Before the Second World War propaganda depicting Britain in a negative light (see chapter 3), Fascism coexisted with the British Empire for many years. What the regime told the Italian people during this period, and 
what Italian culture and media said when relatively free of strict instructions on the subject, can of course help shed light on the direction Fascist Italy's relationship with Britain was taking. However, it can also tell us much about how the regime perceived itself. The perspective would hence not be a study of foreign policy but focus instead on internal Italian discourse. When assessing Fascist relations with the British Empire, Laura Cerasi argued that

the wish to revenge previous humiliations epitomised by the 'shame of Adua', while it certainly dominated Fascism's public discourse, did not account for all the cultural and political significance of the Ethiopian campaign. Growing Anglophobia and the strident anti-British campaign may provide an additional way of understanding this. ${ }^{14}$

How did the regime's representation of British foreign policy and imperialism evolve during the Fascist decades? Was such representation always consistent with Rome's fluctuating relations with London? More generally, how did Fascist Italy relate its growing imperialistic urges with the global empire centred in London? To answer these questions, it is necessary to analyse the writings of Mussolini himself, especially in the early years of the Fascist movement, the Italian media before and after their 'Fascistisation' and British Foreign Office reports about the experience of Britons in Italy.

The events leading to the Second World War are well known. As the relationship between Rome and London consistently deteriorated during the second half of the 1930s, the regime adopted diverse tactics in order to deal with the British. Fascist public discourse had, by then however, developed a distinct anti-British tone. The amount of newspaper articles criticising British foreign policy are therefore numerous, and since they generally followed the expedient political necessities of Fascist foreign policy, they are of relative interest. Henceforth, the chapter will not follow a chronological examination of the late 1930 press analysis of British foreign policy. While the first half of the chapter follows a chronological approach, from the Great War to the Ethiopian War, the second half adopts a thematic approach in order to understand the more peculiar and meaningful aspects of antiBritish discourse, for example, the references to the Risorgimento, comparisons between Britain and Carthage and the assessment of British colonial policies.

\section{The Origins of Fascist Anglophobia: The Great War}

From the time of the Risorgimento, and London's meaningful role in Italian unification, Italy and Britain had traditionally regarded each other in friendly terms. British fascination with Italy, exemplified by the proverbial Grand Tour of the 
country, was well known and permeated 'aristocrats, politicians, dowagers, heirs to landed fortunes, members of the royal family, artists and literary figures of the eighteenth and nineteenth century. ${ }^{15}$ Liberal Italy, meanwhile, always carefully avoided any expression of hostility towards London. Even when Italy joined the Triple Alliance with Germany and Austria-Hungary (1882), it was ever clear to Italian elites that war with Britain was unthinkable. ${ }^{16}$ The British Empire, if only by virtue of its sheer size, had been widely admired - and, of course, envied - by Italian imperialists since the nineteenth century. This fascination was so widespread that, in Laura Cerasi's words, 'in the liberal period [Britain] had represented an unrivalled superiority - individualism, sternness of character and entrepreneurial daring, all of which had supported the expansion of British rule across the world. ${ }^{17}$ Yet a sense of inferiority can bring about resentment. The almost unanimous condemnation in Italy of the British role in the Boer War (1899-1902) showed that respect and admiration did not necessarily descend from an Anglophile attitude. ${ }^{18}$ At the same time, as Cerasi has demonstrated, by the beginning of the Great War the perception that British power was weakening, as a result of domestic as well as foreign factors, was spreading. In Cerasi's words, 'as the first decade of the twentieth century ended [...] it no longer seemed possible to consider the British Empire's gains without also noting various indications of a weakening in its previously unquestioned primacy. ${ }^{19}$

Anti-British feelings had spread in Italy since the very beginning of Italy's participation in the Great War. The famous British historian G.M. Trevelyan described how, in 1916, an Italian sergeant (otherwise not antiwar) had told him that 'you English make it [war] last,' that the war was between the British and the Germans and that the British goal was to close the seas to everybody but themselves. ${ }^{20}$ To this, the sergeant added an argument that would often be repeated by Fascist propaganda years later: that the toll foreign ships had to pay to the British at Gibraltar proved that the British aimed to have exclusive control over the Mediterranean.

Don Giovanni Minzoni, a military chaplain who served on the Italian front during the war and a future martyr of Fascist violence, considered the British the 'new Romans' (remarkably, this time the comparison was meant to be negative), fighting the war mostly with Latin blood and whose eventual goal, once Germany had been subjugated, was to dominate the whole continent. The Socialists had similar thoughts: Filippo Turati, leader of the Socialist Party and another future victim of Fascism, declared to the Italian parliament that the British had every interest in prolonging the war for it meant, for them, an excellent source of business. ${ }^{21}$ On the British side, Hugh Dalton, future Chancellor of the Exchequer 
who was serving on the Italian front, wrote in his memoirs that the Italian soldiers often thought that the British tried to prolong the war. ${ }^{22}$ Journalist and future anti-Fascist, Mario Borsa, wrote a pamphlet in 1915 in which he denounced the 'weird and subtle spirit of distrust and antipathy against England that has infiltrated our people.' Despite traditional British friendship, he wrote, anti-British feeling was growing: 'everywhere you hear expressions of discontent and resentment, criticism, recrimination and denigration. The intentions and the goals of England are questioned.' These tropes - British egotism, Britain's diplomatic and military mistakes and the British tradition of letting others fight and die for them - were often repeated by others. According to Borsa, such ideas had been artificially introduced by the Germans during the period of Italian neutrality. ${ }^{23}$

As widespread as it was, anti-British feeling before the Great War was to increase dramatically after the end of the conflict, when it became clear that Italy and Britain saw the postwar order in radically different ways. The fundamental problem was that the various Italian governments, as well as public opinion, felt that the postwar treaties were unfair to Italy. Meanwhile, the British government believed that the root of the problems with Italy lay in the fact that the war had led it to develop unreasonable and disproportionate imperialistic aspirations, despite various criticisms London had for the Italian wartime contribution. ${ }^{24}$

This, as well as the mistakes made by the Italian negotiators, Prime Minister Vittorio Emanuele Orlando and Sidney Sonnino, his foreign minister, led to Italy's isolation in Paris. Britain's leaders were not particularly stubborn regarding the eastern Italian border, but they were hostile to Italian ambitions in Asia Minor and Africa, which they considered their (and France's) sphere of influence. The fact that the Italians had decided not to stick to the Pact of London in order to take Fiume convinced the British that they could selectively decide whether to support Italy's claims agreed upon in 1915 , when Italy entered the war. ${ }^{25}$

After Orlando's fall and the rise of a new government in June 1919, the new prime minister, Francesco Nitti, was more optimistic about Italy's prospects, recognising that Italy had gained many de facto advantages from the war, including the destruction of the Austrian arch-enemy and the fulfilment of irredentist claims in the northeast. He saw in Britain - but not in France, which he did not trust because of its nationalism - a partner for the reconstruction of Europe and its economy along fair, liberal lines. ${ }^{26}$ On I2 September 1919, after his minister of foreign affairs, Tommaso Tittoni, as part of his attempt to reestablish a good relationship with Britain, accepted the evacuation of Italian troops from Fiume, D'Annunzio organised his famous coup, which led to the creation of the Free State of Fiume. The immediate threat the Vate - as he was 
often known - wanted to prevent was the occupation of the city by a British police corps, which would have made any similar action impossible. In this sense D'Annunzio's move, so important for the future development of Fascism, started as an anti-British action. By that time, the image of Britain in Italy had reached a nadir, with the government doing little to prevent it. Tittoni's attempt to solve all the contentious points in the peace treaties by swift agreement with Britain proved unsuccessful and, frustrated by British rigidity, the minister revealed to the press that the British government had harshly condemned the situation in Fiume and admonished him that Italy was risking 'complete isolation.' The predictable consequence was the unleashing of a new, violent anti-British campaign, this time not limited to nationalist newspapers. ${ }^{27}$

Despite this, Nitti would not give up trying to strengthen his links with Britain. In the final months of his government, he chose British Prime Minister David Lloyd George as an interlocutor, accepting Britain's proposals in the peace treaties and basing his foreign policy decisions on the assumption that collaboration between Italy and Britain was of absolute importance in order to secure British support for solving the eastern Italian border issue. The cost was the sacrifice of Italian ambitions in the eastern Mediterranean. This upset Italian public opinion, which correctly felt that Britain had chosen Greece as its key ally in the Mediterranean at the expense of Italian aspirations in the region. ${ }^{28}$ Nitti obtained nothing, which contributed to the eventual fall of his government in June 1920, to be replaced by a fifth Giolitti government. Giovanni Giolitti shifted Italian foreign policy towards an improvement of relations with France, leading to the Treaty of Rapallo in 1922, which settled the matter of Italy's eastern border. However, relations with Britain worsened due, among other issues, to increased Italian support for Turkish Nationalists and the support given to France on the subject of German reparations. ${ }^{29}$ Mussolini's government therefore inherited a very tense situation in the eastern Mediterranean.

The unpopularity of Britain among the Italian population worried the British Foreign Office and was widely reported by British newspapers. Letters from British citizens to the Foreign Office described an alarming feeling of hostility towards Britain and Britons in Italy. One mentioned 'the treatment likely to be experienced at the hands of our grateful allies. On the third night there was a considerable disturbance outside my window, howling and shouting "Morte a L'Anglais" and after this ceased I heard the sound of a distant crowd howling and booing. ${ }^{30}$ Sir George Buchanan, the British ambassador in Rome, commented that this was only one of many cases. ${ }^{31}$ 
Another example is seen in the letter written by a British citizen with Italian contacts, who mantained that reports of such hostility were not exaggerated and that his Italian friends had told him

there is great resentment against [Britain] and everybody (of course of the lower classes) says: you see, England has induced us to join in the war, and now that she has got all she wanted from us, has given us the 'calcio dell'asino' (the dirty kick out). They think that our bad position at present, economically and politically, is due to the unfaithfulness of England. You can argue for hours, but you cannot dissuade them from this stupid idea. ${ }^{32}$

Indeed, anti-British attitude was not limited to the Nationalists, though reasons varied. Avanti, the socialist newspaper, attacked the League of Nations as the reason the International Labour Conference in Genoa failed and claimed that the chief problem had been the policy of English supremacy. Perfidious Albion, the newspaper wrote, defended their right to exploit Indian workers and had hence prevented the adoption of the eight-hour working day principle. The Avanti article concluded by threatening a boycott of British and pro-British ships, as well as an international marine strike. ${ }^{33}$

The Foreign Office also reported that the liberal newspaper, Il Giornale d'Italia, had adopted a violent, anti-British attitude, criticising the Vatican for being a 'prisoner' of the British government, unable to defend the Irish Catholics. Meanwhile the Tempo wrote that

for Poland, re-arisen to liberty and on the point of losing it through her own imperialistic tendencies and other imperialisms, which the Vatican not dare oppose, a crusade of prayer is ordered. For Ireland, truer and greater martyr, it is thought neither useful nor necessary to intervene. ${ }^{34}$

The report added that, 'for some time past, any pretence at impartiality has been put aside and the tone of the paper has been as frankly anti-Vatican and anti-English.' Il Corriere d'Italia, a Catholic newspaper, joined the anti-British campaign on the topic of Ireland, though in milder tones. One example was an article titled 'The Terror in Ireland,' which condemned the 'destruction' and 'murder' the British soldiers carried out in Ireland, adding that the Irish question cast a shadow on the reputation for civilisation and freedom held by the British. ${ }^{35}$

Fearing Britain from the beginning, D'Annunzio's state in Fiume quickly assumed a decidedly anti-British attitude, acting as a hub of 'anti-imperialism.' The fact that most of Fiume's 'Legionaries' were also Nationalists who felt that 
Italy had been deprived of its vital space by the peace treaties was an inconsistency that was not yet obvious, for many Italians still perceived themselves as a 'proletarian' nation, as much victims of imperialism as the Egyptians. The British Department for Foreign Affairs received more than one worrisome report from Fiume. Alceste De Ambris, revolutionary syndicalist and fundamental contributor to the new state's constitution who was to become a fervent anti-Fascist, delivered a speech in which he described Fiume as just one of the many countries that suffered the vexations of international bankers who 'would monopolise nations and souls.' The enemy was soon identified in the Anglo-Saxon powers:

Heroic Belgium, after her martyrdom, finds herself at England's mercy. Ireland, Egypt and the Soudan [sic] support with difficulty the hegemony of the enormous empire. The Latin republics of South America undergo with terror the ever stronger grip of the United States. ${ }^{36}$

De Ambris concluded that, since the West refused to recognise Fiume's Council, only a cordial rapprochement with the East could assure the prosperity of the new state. The former Austro-Hungarian states, as well as Russia, could alone assure Fiume's economic prosperity.

Another letter reported a declaration by the Department for Foreign Affairs of the Republic of the Council of Fiume, addressed to Sir Eric Drummond, 'secretary general of the pseudo-League of Nations,' stating that the league was 'nothing other than an instrument [that] the British Empire and the other capitalistic states are planning to use to assure their hegemony over the world.' Other reports concerned the relationship between Egyptian Nationalists and the Council. The latter stated that

the atrocities committed in a few months by the British troops outbid beyond a shadow of a doubt the most serious misdemeanours perpetrated by the German troops in Belgium and France. Peaceful and inoffensive meetings were dispersed by machine guns, by flames and poison gases, and by the most atrocious and perfect war inventions [that] have ever fallen into the hands of the most cruel people on earth. Hundreds of villages were systematically burned after the previous execution of the whole male population. The English soldiers knocked down without pity the women and the children who attempted to escape from the flames. In a few months more than 70,000 people were massacred [...]. The Command of Fiume hails with joy the young nation, which on the banks of the Nile witnesses the first civilization of mankind, arises and proceeds towards a new destiny. ${ }^{37}$ 
The Council dispatched letters to other rivals of Britain. In one communication to the Turkish Nationalists, De Ambris and the Belgian Leo Kochnitzky described Britain as a 'voracious empire, which, after having subjugated twenty Musulman $[s i c]$ races, today aspires to seize Constantinople' and boasted how the Legionaries of Commandant D'Annunzio had 'put to flight the English police bullies who were biding their time to snatch the tortured city, already preparing to make a landing. ${ }^{38}$ Henry Furst, an American journalist who played a key role in D'Annunzio's recognition of the Irish republic, wrote to the president of the Irish parliament stating that 'the heart of Catholic Ireland has always had the love of her sister, which penetrates to her across the interposed barriers of cold materialism and rigid reason, France and England. ${ }^{39}$ As a group of university students from Bologna proclaimed, Italian Fiume must be defended against 'the coalition of the arrogance of Anglo-Saxon bankers, of French envy, of Yugoslav barbarism. ${ }^{40}$

This resentful attitude so common in Italy at the time predictably found a champion in Mussolini. If during the war he had been a consistent Anglophile and had received subsidies from the British embassy, now Mussolini was as harsh as anyone in his tirades against Britain. ${ }^{41}$ Already, in January 1919, he had reminded his readers that Malta was not yet redenta (redeemed), and in June of the same year the Fascist Central Committee approved a declaration of solidarity with the Maltese Italian Nationalists. ${ }^{42}$ On 20 April 1919, the future Duce claimed that no country had opposed Italian aspirations as much as Britain, treating the peace conference as business and leaving Italy almost nothing. In order to contrast rising Anglo-American hegemony, Mussolini explained that Italy could soon join the anti-British block, clearly implying that it meant to side with a revanchist Germany, threatening, thanks to its geographical position, the British Empire in the Mediterranean. He threateningly predicted that

I tomorrow carry out the task of blowing up the Asiatic-African English empire, even more so since there is no lack of native unrest [...]. This note does not want to anticipate what can happen; it wants to influence, at the last minute, the four wise men who will today decide on our issues. ${ }^{43}$

While Ireland was far, Mussolini hinted, Egypt was close. If Britain chose not to recognise Italian rights, 'our politics for tomorrow' will be oriented towards 'establishing a bit of justice between us proletarians and the fattest and [most] bourgeois nation in the world.' A few days later, he reiterated the same claims, and threatened that

if the Anglo-Americans [were] to strangle us with the blackmail of wheat and coal, we have other cards [to play]. We are in contact with the English 
colonial empire. From Egypt to India, all that world is in insurrectional turmoil. If we are betrayed we will immediately prepare our redress ${ }^{14}$

British egoism, the contrast between the rich, satisfied and proletarian nations of the world, but also anxiety over the vulnerability of Italy to Allied blockade and the geopolitical prominence of Italy in the Mediterranean, prove that many of the ideas inherent in future Fascist anti-British rhetoric already existed.

Mussolini was convinced that, after having finally got rid of its Habsburgic and Prussian masters, Italy was now under the heel of the Allies:

It is forbidden - manu militari - to have a feeling of solidarity for Ireland; it is severely forbidden to sympathise - in the name of law and justice [with] the Egyptian insurgents. In Rome there is no Italian government [. . .]. In Italy, the trembling and cowardly government, is always at the orders of someone, never at the orders of the nation. ${ }^{45}$

Nitti's overtures towards Britain were ridiculed by the Fascists, whose anti-British rhetoric sharpened during 1919 and 1920 to the point that the Central Committee voted on a declaration of sympathy for the anti-British Egyptian revolt, as D'Annunzio's Fiuman state had done. ${ }^{46}$ It was at this time that Mussolini started shaping an idea of Fascist imperialism, which he described as 'an eternal law of life'; already Mussolini defined his own Roman imperialism by contrasting it with the 'other. ${ }^{2} 7$

Considering all of this, the British government was understandably worried, but soon after coming to power Mussolini assured London that his anti-British rhetoric would not last. After meeting Mussolini, British Ambassador to Rome Ronald William Graham found him moderate and reasonable. In any case, Mussolini's first diplomatic experiences showed that he had not forgotten his past words about Britain. After his unsuccessful participation in the Lausanne Conference (1922-1923), he threatened to break the postwar alliance with Britain and France if Italy did not receive a mandate in the Middle East. In addition, he eventually sided with the French against London regarding the question of German war debts. Furthermore, Mussolini expressed his hope that the British Empire would break up under the pressure of a pan-European block so that Italy could take its spoils. It was at this point that he instructed the Italian press to assume an anti-British tone; and so they did, even those newspapers that were not in Fascist hands. ${ }^{48}$ Il Corriere della Sera (hereafter Il Corriere) started publishing anti-British articles originally published in France, emphasising London's responsibility for the crisis in the Entente. Luigi Luzzatti, former president of the Council of 
Ministers, criticised Britain's double standard and egoism concerning financial issues. ${ }^{49}$ Disturbed by the British press' reaction against him, Mussolini changed his course, moderating his words and strenuously denying his fantasies of an anti-British block. The Italian press started doing the same, while still mentioning British responsibility for the crisis. ${ }^{50}$ Il Corriere had to reassure the British, writing that while Italy was indeed Francophile, it was not Anglophobic, and that Italy was of course not planning a naval war against Britain. The fact that such an article (and it was not the only one) had to be written, however, shows how tense the situation had become. ${ }^{51}$ While Ambassador Graham wrote to London that Britain was 'not just respected, but liked' in Italy, even he felt some distrust for Mussolini, considering him unreliable. ${ }^{52}$ Postwar Anglo-Italian relations had never been idyllic; in April 1923 a Foreign Office report described them as barely changed after the rise of the Fascisti. In June, the British Royal Family visited Italy and were welcomed by 'an outburst of spontaneous enthusiasm. ${ }^{53}$ The Italian press celebrated the visit, but did not forget the strains of the past and warned readers not to delude themselves about the British attitude towards Italy. ${ }^{54}$ The relations between the two countries were hence still uneasy, but the worst was yet to come.

\section{The Corfu Incident}

Tension between Greece and Britain on one side and Italy on the other peaked with the Corfu crisis of 1923, which exposed the frailty of the Italian people's new appreciation for Britain. When in August five members of an Italian mission on the Greek-Albanian border (including a general) were murdered, Mussolini sent an ultimatum to Greece. Greece accepted most of its demands. Unsatisfied, the Duce proceeded to bombard and occupy the island of Corfu, killing some refugees in the process. While France's response was soft, Britain was harsher and would have preferred the subject to be debated in the League of Nations. A compromise was eventually found, but Mussolini was only dissuaded from keeping the island under Italian control by the threat of action from the Royal Navy. While internally presented as a triumph of Mussolinian diplomacy, with Greece humiliated and Britain forced to accommodate Italian demands, the Corfu episode damaged Mussolini's image abroad. ${ }^{55}$ The reaction of the Italian press, which was still not completely under Fascist control, was unanimously anti-British, though in different ways. ${ }^{56}$ Even moderate newspapers such as La Stampa - which had thus far managed to preserve a certain independence from Fascist control - were disappointed by the British attitude. ${ }^{57}$ Another moderate newspaper, Il Corriere, was surprised: 
Italy, after having walked with the Allies to the end of the harsh Calvary of the war and of the postwar period, after having given every proof of moderation and sacrifice to keep the general peace, had the right to expect from England and France a show of full and complete solidarity. We faced, instead, open English hostility. ${ }^{58}$

The Fascist newspapers were, predictably, even harsher. Mussolini’s daily, $I l$ Popolo d'Italia, claimed that Britain preferred Greece over Italy and that traditional Anglo-Italian relations were under threat, while Il Secolo wrote that traditional Anglo-Italian friendship required, in London, a weak and restrained Italy. ${ }^{59}$ Il Nuovo Paese, a newspaper under strict Fascist control, which had previously adopted an uncommon pro-British attitude - professing admiration for British imperialism, cheering the moral principles that inspired, together with national interests, British politics, and praising British-Italian friendship - suddenly changed its tone. Discussing a British defeat and the 'people of the five suppers,' using bitter irony, Il Nuovo Paese used words that closely resembled those that were to become so common during the Ethiopian crisis. ${ }^{60}$ The League of Nations was widely reviled, and its reputation as a tool of Britain was by then so entrenched that attacks on one reflected on the other; for example, the journalist and future infamous war propagandist, Virginio Gayda, described the League as a 'syndicate of interests of the Anglo-Saxon race. ${ }^{\text {'1 }}$ The most vehemently imperialistic (as well as anti-Semitic) of the Italian newspapers, Impero, used the same kind of verbal violence, which would later become the norm during the Ethiopian War, and did so for months after the Corfu incident was over. The Anglo-Italian friendship was dead because Britain wanted to prevent Italy's 'coming of age,' that is, becoming a true Great Power. The British Empire was, like that of the Habsburgs, doomed to disintegration. Mussolini's victory was against Britain, not Greece, and since it was now clear that since London and Paris were unable to rebuild the European system, the Mediterranean belonged to the Mediterraneans. ${ }^{62}$

Corfu was a traumatic event for Mussolini: the British reaction, coupled with the strengthening of the British position in Malta, showed that London was ready to resist any Fascist attempt to pursue an aggressive policy in the Mediterranean. ${ }^{63}$ On the other hand, historians have claimed that, far from being an aberration, Corfu had shown the real nature of Fascist diplomacy. ${ }^{64}$ More to the point, the crisis proved that anti-British feeling, so common during and after the war, had not disappeared and that this was still prevalent among the Fascists and their nationalist flankers. Following the end of the crisis, the most violent aspects of 
anti-British feeling receded, but only slowly, while articles attacking Britain lingered for years. For example, as late as September 1925, Camillo Pellizzi, who had started to become one of the harshest Fascist critics of Britain, felt the need to contest the opinion Italians held of the British Empire, which was that 'Wicked Albion grabbed, devoured, exploited. ... The world has to work to fatten the people of the five suppers.... A tyrannical, selfish, hypocritical people. ${ }^{65}$

\section{After Corfu: Cooperation and Tensions}

Now aware of the limits to how far he could push London - and temporarily paralysed by the Matteotti crisis (1924-1925), which jeopardised his international reputation - Mussolini started a long phase of relative cooperation with Britain, at least in Europe. ${ }^{66}$ The necessity of consolidating his regime, tensions with France and Yugoslavia and the attempt to obtain Anglo-American cooperation to stabilise the Italian economy, as well as Mussolini's friendship with British Foreign Secretary Austen Chamberlain, eased the development of a friendly relationship between the two countries. ${ }^{67}$ However, Mussolini never forgot Corfu and the harsh reality of his vulnerable position when confronted by Britain. The claustrophobic feeling of being strangled by what he saw as his Mediterranean prison was to prove the key motive behind his foreign policy, sometimes hidden but always present. In 1925 he told the Italian diplomat Salvatore Contarini that 'Gibraltar, Malta, Suez, Cyprus represent a chain that permits England to encircle, to imprison Italy in the Mediterranean. If another link, Albania, were added, we would have to break it with a war. ${ }^{36}$

In late 1926 or early 1927, Mussolini stressed to his army general staff that Italy needed access to the oceans to become a Great Power and, in 1929, stated that Italy could not remain a prisoner of the Mediterranean. ${ }^{69}$ However, for the moment, Britain was not the target of his aggressive foreign policy, for already in 1926 Mussolini had turned his hostility towards France. Not unlike Hitler in the following decade, when targeting one adversary the Duce tended to forget others; hence, there was now room for a new kind of representation of Britain by the Italian media.

During the second half of the I920s, tensions between Britain and the Soviets - and to a far lesser degree with the United States - led some Fascist commentators to associate Britain with the security of the European continent. This corresponded, more or less, with how Fascism was seen as a bulwark against Bolshevism by many British conservatives. At the same time, there were doubts as to how far Britain could protect Europe in her current state, which many 
Fascists perceived as severely weakened. In 1927, Manfredi Gravina, Nationalist and future supporter of an alliance with the National Socialists, described the British Empire as an essential part of European civilisation, necessary to contain the desegregating influence of Bolshevism and the rise of the 'coloured' races. The British Empire, in Gravina's eyes, was a global extension of the European continent; it had to choose whether to abandon itself to decline or to represent Europe in the world. ${ }^{70}$ Gravina's article depicts, perhaps more than any other, the attitude of the pre-Depression Fascist press. The British Empire, not British metropolitan society, was seen as a force of stability yet, at the same time, as a declining force. Indeed, during the second half of the i920s, the decline of the British Empire was seen by some Fascists as a threat to European civilisation and the 'white' race as a whole. In April 1930, La Stampa warned that if India was lost by London the British Empire was doomed, but also that its collapse would be fatal to European supremacy in the world. ${ }^{71}$

Good relations with London meant that a relatively diverse debate on Britain could emerge among Fascist intellectuals, so that other commentators proved more or less optimistic regarding the conditions and eventual fate of the British Empire than Gravina, while sharing his basic premise. Some commentators were optimistic and admired the organisation and racial hierarchy of the Empire. ${ }^{72}$ In July 1928, Nicola Pascazio contested the notion that the British Empire was dying, devoured by the Dominions' pressure for independence; the fact that he felt the need to contest it suggests how pervasive the idea of British decline already was, even before the Great Depression. According to Pascazio, there was evidence that the sunset of the British Empire was neither 'immediate, nor near. ${ }^{73}$ He denied Soviet claims that the British Empire was already in a 'revolutionary phase': 'Bolshevism and Islamism, poisons that run through its veins, [...] do not disturb the substance [of the Empire].' Pascazio believed that the new Italian man, forged by Mussolini, could look at British imperialism as an example: 'if he must look at lifestyle, if he has to devote his attention to a state-system, if he must ask for enlightenment to an imperialism, this must be the English. ${ }^{74}$ It was indeed the British cynical calculation of national interest and outspoken declaration of imperialistic goals that Pascazio admired and hoped the Italians would emulate. This relatively Anglophile attitude emerged during a particular moment in the development of the Fascist regime, already consolidated but not yet in its totalitarian phase, a moment in which traditional conservatism could think of the regime as a source of traditional order. On the domestic front, Mussolini had proceeded to restrain the remains of the squadrismo, empowering the prefects in an effort to strengthen the State against the Fascist Party. ${ }^{75}$ Abroad, 
some commentators felt that Italy was finally enjoying the respect of the world and was now considered a true Great Power; siding with Britain against the double menace of the rise of the 'coloured' race and of Bolshevism was a projection of this 'respectable' and 'institutional' attitude, which would not have survived for long.

However, as H. James Burgwyn explains, Mussolini's envy of the British Empire and his support for revisionist factions in Eastern Europe meant that the Duce was still considered an unreliable partner in London. ${ }^{76}$ Furthermore, while stable in Europe, the relationship with Britain was tense in the Red Sea, to the point that the situation has been described as a cold war. ${ }^{77}$ Not yet able to pursue his goals in Europe, the Duce pursued a 'policy of imperial expansion in the Mediterranean and in the Red Sea. ${ }^{78}$ The establishment of greater Italian influence in Yemen rested on the support of Imam Yahya, who eventually launched raids on British territory in the Arabian Peninsula. When, unavoidably, the British reaction led to aerial bombings of the Yemeni position, Mussolini made it clear that he refused to support the Imam in a war against Britain. ${ }^{79}$ The Italian press covered the topic without expressing overtly anti-British tones. Il Corriere celebrated growing Italian influence in the country by underlining how, unlike the British, the Italians did not want to reduce it to a protectorate. ${ }^{80} \mathrm{When}$, in summer 1927, the Daily Telegraph announced an imminent treaty between Britain and Yemen, Il Corriere resolutely denied this had happened. ${ }^{81}$ However, when the British started bombing the country, while maintaining an insistent focus on the civilian suffering it caused, the press treated the subject as a purely Anglo-Yemenite matter, irrelevant to Italian national interests. ${ }^{82}$

The severity of the Great Depression was judged by many Fascists as certain to weaken the British Empire. Already, in January 1930, Virginio Gayda described 'the awakening of India' caused by insufficient British lucidity, weariness of British colonial bureaucracy and the decline of British prestige. ${ }^{83}$ While Gayda temporarily moderated his previously Anglophobic views compared to the early I920s, he considered Britain an obviously decaying power. Less optimistic than Pascazio, he thought, however, that the crisis of the British Empire was 'vast, but not desperate,' and maintained that British goals and European cooperation were antithetical. While Pascazio had deemed an Anglo-American alliance unlikely given the contrast between the two powers' interests, Gayda noted that the British Empire was getting closer to the United States, accepting naval parity with the other Anglo-Saxon power. ${ }^{84}$ Gerarchia's contributor, Giacomo Redentini, was even more pessimistic than Gayda, writing that the Depression was going to push the declining British Empire and its lazy, comfort-loving people into 
isolationism. ${ }^{85}$ Three years later, in an identical tone, La Stampa described the 'weakening of British prestige in the world, paralyzing uncertainty in the fields of international and internal politics. ${ }^{96}$ The British Empire's perceived state of weakness fuelled predatory appetites among Fascist commentators; articles concerning Italian interests in and influence over British Dominions or colonies such as South Africa, Malta and Canada started to appear in newspapers and magazines, including the important Gerarchia. ${ }^{87} \mathrm{~A}$ harsh anti-British, irredentist campaign focusing on Malta appeared in the press in the first years of the new decade. While the Maltese issue was not a new one, Fascism, as Claudia Baldoli explained, brought it to an extreme point, considering Malta an Irredenta land and building an anti-British, anti-Protestant campaign starting from $1928 .^{88}$

Interestingly, general criticism of British imperialism, and of its hypocrisy in particular, resurfaced - though in a very mild form when compared with what was to come - in these years. In late July 1932 Mussolini dismissed Foreign Minister Dino Grandi because he was considered too Anglophile, 'exiling' him to the embassy in London. In October 1932, La Stampa commented that the British had managed to convince the world that their imperialism saved and helped the peoples it conquered, and in March 1933, Il Regime Fascista bitterly observed that the Anglo-Saxons could afford to deem war as a crime because they were 'oversated with plundered land. ${ }^{89}$ The perception of British weakness was the cause of this change in attitude. After all, this was the time when Mussolini felt that, as Robert Mallet put it, a bubble reputation - that is, foreign policy oriented towards merely seeking prestige - was no longer enough..$^{90}$

\section{The Ethiopian War}

With the onset of the Ethiopian crisis, things changed radically, and the regime instructed the press much more thoroughly, trying to adapt the tone of newspaper articles to the necessity of changing diplomatic circumstances. In May 1935, the press was ordered to adopt a tone of 'cold hostility' towards Britain. ${ }^{91}$ The major newspapers had to answer any attack by the British and it was noted that 'very soon it will be up to the whole Italian press to do so.' The Italian press indeed went ahead and hammered the British. Given the opinion that Manlio Morgagni, the head of the Fascist press agency Stefani, had of Britain was that of 'the great murderer of ideals, ignoble and egoistic and repugnant at every hour and at all times, the great criminal of history,' the basis for the campaign was set. ${ }^{92}$ When Anthony Eden replaced Samuel Hoare as British foreign secretary, he was targeted in particular as the embodiment of British 'perfidy. ${ }^{\prime 9}$ 
At the end of July, after the British had removed the embargo on gun sales to Ethiopia and affirmed their commitment to the ideals of the League of Nations, the press was ordered to start 'polemics against the British press without attacking the government. ${ }^{.94} \mathrm{~A}$ few days later, the order was to refrain from attacking Britain at all. ${ }^{95}$ Between $15-18$ August, a mediation attempt by Eden and French President of the Council of Ministers Pierre Laval was rejected by Mussolini, but on 19 August the press was instructed to stop attacking Britain and to answer any attacks by the British press, while on 2I August the order was to stop polemicising completely. ${ }^{96}$ One interesting example of the Fascist understanding of the situation is the report, read by Count Galeazzo Ciano - who was at the time minister for press and propaganda - and Mussolini, which was written by Pier Filippo Gomez Homen, a journalist and Fascist intellectual recently back from a trip to Britain. The report was full of contempt for the British and presented its own explanation of the Anglo-Italian crisis. According to Gomez Homen's analysis, the reasons for British hostility towards Italian action in East Africa could be traced to the fact that, being an election period, the government needed to gain the support of a pacifist and internationalist public opinion. British public opinion, according to Gomez Homen, was inclined to indifference, laziness and provincialism, so very few knew anything about the crisis; they only knew that the Italian press had attacked Britain and that Italy wanted war, while the British only wanted 'peace, peace, peace.' It was perfectly possible, Gomez Homen wrote, that if elections had not been close, the Abyssinian question would have remained limited to the Foreign Office and the Parliament. However, some conservatives like Eden had decided to capitalise on the people's thirst for peace in order to gain votes. 'The anti-Italian campaign has been orchestrated for electoral means,' the journalist wrote, adding 'it is aimed at gaining the votes of

I. the anti-Fascists, Labourists or otherwise, that still have not forgiven the fact that Fascist Italy exists;

2. the Geneve pacifists, which are the bulk of the voting mass, and that can be identified with the average Englishman, who is a lazy, egoistic upstart;

3. the colonialists, [...] who traditionally feel nothing but a haughty contempt for any colonisation methods that are not English.'

Gomez Homen's advice to the regime was to ignore the British' anti-Italian press, not to answer it and to work through official channels: 'We have woken the big electoral bulldog. Let's see if we can put it back to sleep. ${ }^{97}$ On 23 August, Ciano ordered the press to 'absolutely forget England. English news and newspaper comments can be published; but do not absolutely polemicise. Show cold contempt. ${ }^{98}$ 
The attacks never really ceased, however, and by September they were as strong as before, so the press was once again ordered to suspend its attacks against British newspapers on I October, when a temporary relaxation of the tensions between the two countries took place (for Mussolini was now reassured that Britain would not have chosen war).99 On 3 October 1935, Italy started military operations against Ethiopia and the Italian people had to be kept ignorant of British military measures in the Mediterranean. ${ }^{100} \mathrm{~A}$ few days later, the orders to the press were the following:

With regard to Britain, reasons of caution force us not to polemise excessively, after all, next week will definitely make the situation clear, news coming from England can be published but without overrating anything, and without uncovering our game. ${ }^{101}$

On is November, a 'reserved' attitude had to be adopted regarding France and Britain, and Vittorio Alfieri - now under-secretary of the ministry of press and propaganda - repeated the message on 18 November, the reason possibly being the prolonged military stasis on the Ethiopian front and uncertain developments in the crisis. ${ }^{102}$

British Foreign Secretary Samuel Hoare's speeches were to be ignored, his replacement to be commented on with only a few words, and when Eden - who was notoriously reluctant to appease Mussolini - replaced him, this was not to be mentioned. ${ }^{103}$ Once revealed, the Hoare-Laval proposal to negotiate an end to the war by forcing the Ethiopian Emperor Haile Selassie to make substantial concessions was to be criticised as 'a disappointment for public opinion,' but the press had to restrain from attacking France and Britain. ${ }^{104}$ During the final months of the war, the orders to the press stopped trying to moderate the attacks, instead encouraging them. The cracks and the harmful effects of the pro-sanction front were to be emphasised. For example, the press had to underline how Britain refused to refund the losses other countries had suffered because of the sanctions. ${ }^{105}$ However, the orders to the press did not bother with details of the polemics; the themes were roughly the same as we have already seen in times of past crises with Britain. The most common feeling at the beginning was resentment: Why did Britain make common cause with slavers and Africans against its ally of the Stresa front? The answer was found in British egoism, as well as a sense of superiority. Other old themes were the claim that the League of Nations was a scam and a tool of London's or that, since British ruthlessness was at the base of its empire, it was a great hypocrisy not to accept that Italy had the right to do the same. ${ }^{106}$ Others, however, were new: the British Empire was 
no more the declining bastion of the white race in the world; instead, Britain was betraying the white race by siding with 'nonwhites' against Italy. ${ }^{107}$ Ironically, it was the Fascists who subverted the other 'pillar' of the united Western camp appreciated by people like Gravina, the common hostility against Bolshevism. In December 1936, Gerarchia published an article that encouraged the Soviet Union not to repeat the errors of the Tsars, who had refused to follow Napoleon's advice to invade India. ${ }^{108}$

\section{After Ethiopia}

The end of the Ethiopian War in May 1936 put Italy in a delicate situation. Mussolini soon involved himself in the Spanish Civil War, leading to further tensions with Britain. Already in May, by virtue of the attempts to normalise relations with Britain, Ciano ordered the press to 'omit any polemic attitude regarding Britain,' and in June the press was repeatedly ordered not to talk about Britain at all. ${ }^{109}$ Anti-British hostility resurfaced in the press in the following months and in May 1937, a few days after Il Corriere had run columns saying that Britain was 'against European peace,' the press was ordered to avoid any attack and not to refer to attacks coming from other countries. ${ }^{110}$ Two months later, the disorders in Ulster (where the IRA attempted to assassinate King George VI) were to be ignored and the press had to underline, without any further comment, the moderate attitude of the British press. In August, comments on the Italian-British détente had to be softer on France as well. ${ }^{111}$ When in September the Conference of Nyon excluded Italy, the press was ordered to keep a reserved and cold tone. ${ }^{112}$ Such a moderate attitude was confirmed in winter, but only concerning the Spanish issue, while anti-British propaganda was acceptable around Palestine. ${ }^{113}$ This line wavered in November. On the first of that month, Alfieri stated that 'the moderate attitude of the Italian newspapers regarding [Britain] can be toned down, and in the case of attacks by English newspapers the press can answer and attack.' On 17 November, while not changing these dispositions, the relationship with Britain and France was described by Alfieri as in 'waiting.' President of the Council and Leader of the House of Lords Edward Wood of Halifax' meeting with the Germans was to be reported without jealousy, trusting the good faith of the Germans. ${ }^{114}$

Now, alongside the traditional anti-League rhetoric, the claim that Britain was supporting Bolshevism appeared. ${ }^{115}$ On 26 January 1938, the order was to reduce the news coming from France and Britain and to stop publishing comments from foreign newspapers about the opportunity to recognise the Italian 
empire. In general, little relevance was to be given to the Anglo-Italian talks of February 1938 and the 'semblance of relaxation of Italian-English relations' was not to be commented upon. ${ }^{116}$ In June, the newspapers were ordered to stop debating with their British counterparts regarding the bombings in Spain, and when the Anglo-Italian agreement was finally ratified, the newspapers had to refrain from talking about its application. ${ }^{117}$ According to a report written by Alfieri in August 1938, there was 'no sign of improvement concerning relations with Britain, also because of the effect of the Spanish issues. ${ }^{\prime 18}$ During the $\mathrm{Mu}-$ nich crisis of September 1938, British Prime Minister Neville Chamberlain's mediation request to the Duce had to be emphasised. ${ }^{119}$

What do these orders tell us? First of all, as we have seen, they did not usually try to explain the details of what the press had to say, often seeming content with hinting the general direction. The remarkable fickleness of the orders might reflect the uncertainty of those who wrote them; the complex relations with London in the second half of the r930s partially explain this. As Alfieri noticed in winter 1937 , relations with Britain were so volatile that the press must not exaggerate in any direction. ${ }^{120}$ Another reason might be that Ciano, and later Alfieri, were not sure what Mussolini actually wanted. Another point of interest is that the regime's attempts to moderate the violent attacks of the press against Britain, which risked hampering Mussolini's diplomacy, suggests that Anglophobia was not simply the product of a hysterically nationalist regime but rather a current of Italian Fascist culture, which would again and again reemerge in times of crisis. Its tropes show a clear consistency from the beginning to the end of the Fascist era.

\section{Two Imperialisms: Rome and Carthage}

The Ethiopian War and the sanctions brought Fascist Italy's nationalistic exaltation to its peak. If the perception of Britain as a nation and a European force was changed by this development, so was the perception of the British Empire. The notion that the British Empire was founded on a different ideological and philosophical base than that of Italy was not unheard of. One pioneer of this and other kinds of anti-British discourse was Camillo Pellizzi. Already in 1925, he had written his essay 'Cose d'Inghilterra,' in which he stated the following:

Naturally, the British Empire is engraved with the seal of the difficulties from which it arose. It bears a somehow commercial and bourgeois character. It doesn't possess a profound spiritual unity. It doesn't carry any 
substantial mystical and aesthetical imprint. Its meaning and ethical value are very vague, and not exceedingly profound. The comparisons with the Roman Empire, so often made by British authors, should show the latter in advantage. The only ethical purpose of the British Empire is to allow freedom of trade and industry of the European kind in almost the entire world. It's a commercial empire, granting freedom over the seas for all trades, and the opportunity of exploitation of entire continents for the Europeans, better still if Anglo-Saxons. ${ }^{121}$

Two years later, Ettore Pais, an important historian of antiquity who was very close to Mussolini, had already compared Britain to Carthage, describing Rome's African rival in his 'History of Rome during the Punic Wars' as an empire with no martial vigour, whose successes depended on its ability to use diplomacy and wealth. Pais' reference to Britain was neither hidden nor subtle, for he drew comparison between the Carthaginian and the 'Modern Briton (Britanno)' and wrote of how Carthaginian methods were reminiscent of the ones of 'maritime nations of the modern times.' ${ }^{\text {'2 }}$ It was not yet a substantial ideological criticism, but the comparison's implications were obvious and heavy, especially since Pais' work was clearly aimed at glorifying Fascism by describing the glories of Rome. A more ideological criticism was formulated one year later by Nicola Pascazio, who in an otherwise pro-British article wrote that, while for the Italians empire was an idea, for the British it was a fact, the implication being that whereas Fascism had inherited Rome's spiritual empire building, London's empire was but a product of materialism. ${ }^{123}$ The Ethiopian War brought these themes to maturation. In December 1935, Pais wrote an article titled 'Roman Imperialism and British Imperialism.' Pais claimed that whereas Rome integrated and absorbed the most diverse conquered peoples, to the point of being eventually ruled by emperors descended from these communities, the British always considered themselves superior and above their subjects. Unlike Rome and just like Carthage, Britain focused on exploiting its conquests for the benefit of its aristocratic classes. Again, unlike Rome, the historic Punic power and Britain did not extend all the advantages of their empires to their colonies and subjects. A more obvious analogy was the maritime strategy that informed Carthage's foreign policy:

The diffidence and cleverness with which the Punic metropolis used to forbid other states the chance to navigate towards its ports and colonies is reminiscent of how the British people acquired strategic points, for 
example, Gibraltar became de facto master of the Suez Canal and aspires today to rule the whole African continent. ${ }^{124}$

Pais would return to this theme in 1938 in with a book entitled aiming at educating Italian Fascist youth, more or less repeating the same themes of his past essays, even if by browsing the text the reader has the feeling that Pais had warmly accepted the notion that the differences between Rome and Carthage had racial rather than cultural explanations. ${ }^{125}$ The scholar of antiquity was not alone. In 1937, the difference between Roman and British imperialisms was ascribed by Camillo Pellizzi to the rejection of the 'Caesarean' principle by the latter. This rejection had an ancient origin: starting with an analysis of Shakespeare's Julius Caesar, Pellizzi concluded that British culture was deeply conformist and considered faithfulness to one's caste and monarchy the foundation of their national life; it therefore could not forgive Caesar's rebellion against the Republic and his restructuring of the Roman social order. This rejection meant that 'the same British Empire, even if founded on a Caesarean premise, denies it in its political mythology and hides it with its propaganda.' ${ }^{126}$

Still, in 1937, Riccardo Astuto, a former governor of Eritrea, wrote an article for Gerarchia in which he analysed a pamphlet by the British Fascist James Strachey Barnes entitled Roma o Cartagine? Barnes compared Fascist imperialism, which he described as 'architectural,' that is, devoted to building 'something that is beautiful and permanent,' with the British one, 'animated by Carthaginian spirit.' Astuto agreed and explained the difference between the two: whereas the British introduced laws and good rule in the colonies, the Roman, or Fascist, imperialism aimed at integrating, with constructive spirit, the colonies in imperial unity with the metropolis. Economically, the British only plundered their colonies, using them as a market for British goods, while Fascism valorised them. British imperialism, concluded Astuto, 'is not constructive. It lacks social and economic building.' Astuto's conclusion was clear: Africa was a land still open to colonisation and valorisation and Britain was not up to the job. It was Italy's turn, for it 'did not want to limit itself to rule the land, but it wants to build an empire on it.' A key element was Fascism itself; liberalism fuelled resentment and rebellion, while Fascist rule in Eritrea and Somalia had already managed to create imperial patriotism. ${ }^{127}$ Another article in Gerarchia tried to find a philosophical explanation for the faults of British imperialism. According to Elio Vocca, the strength of Britain rested, like that of Rome (and Fascism), on an era of great dynamism. However, whereas Rome's empire was based on 'a breath of eternity' and on universality, the British had no notion of the 'why' and 'where' 
of their civilisation. Vocca ascribed this trait to Hobbesian philosophy based on fear and materialism. Losing one's wealth was Hobbes' greatest fear and that justified the 'people of five suppers' assumption that the only goal of life was pleasure - an 'unbearable idea for us Latins.' Such a 'purely egoistic and materialistic' worldview justified an imperialism that was but exploitation and destruction. ${ }^{128}$ Without great principles to sustain it, all conquests of British imperialism were sterile and evanescent. ${ }^{129}$ In 1938, articles continued to appear in Gerarchia that attacked the British Empire's very nature. Curzio Villa flatly denied any similarity between Roman and British imperialism, a comparison that had often been made even by Fascist authors. The Roman citizen was completely different from the Victorian businessman, while British imperialism was based on the particular treatment reserved for different subject peoples, hence lacking the great Roman concept of universal justice. Such a claim shows how Villa clearly had no notion of how the Romans administered the conquered peoples. ${ }^{130}$ It is interesting to note how Villa's criticism was completely reversed by the racist Lidio Cipriani in 1942, who claimed that the problem with British imperialism was that the British forced their laws upon the whole world without caring for the differences between their subjects, unable as they were to distinguish between peoples and situations. ${ }^{131}$

This wave of articles appearing in 1935-1938 was something new; it was not just the ritual criticism of British greediness that had been the norm in periods of crisis with London. It was instead the first time that systemic criticism of British imperialism, described as something inherently different and inferior to its Fascist counterpart, appeared in Fascist publications.

What caused such a development? Laura Cerasi wrote that 'as Grandi observed in his diary in January 1929, the British as a whole were "cold, uncultured and very great, like the Romans," arguing that such a statement underlines how the Fascist regime perceived Britain with a mixture of envy and admiration.'132 Such admiration was mixed with the hope that, as British power had peaked, it would eventually decline and Fascist Italy could take its place. ${ }^{133}$

As the Great Depression hit Britain hard, and the weight of both the Dominions and colonial empire grew, many Fascists thought that their chance might be coming soon. Cerasi concluded that, "by claiming the legacy of "Romanità" in the Mediterranean, Fascism revealed its intention to compete with the British Empire. ${ }^{\text {'134 }}$ This reappropriation of Roman heritage, Cerasi wrote, was particularly important both because the British had ascribed it to themselves for a long time and because the imperial dimension was fundamental to the Fascist conception of the State. Analysing Virginio Gayda's 194I article, in which the 
journalist compared Britain with Carthage, Cerasi wrote that while many Fascists during the 1930s had begrudgingly recognised the 'unparalleled virtues' of the British people and their empire, by the Second World War the enmity between the two peoples had brought about a decisive turn in Fascist discourse against these values, so that 'industrial and commercial modernity' were now a negative feature. ${ }^{135}$

However, as we have seen, the British Empire was not described, neither during the early phase of Fascism nor during the 1930s, univocally in such rosy terms. In this sense, a systemic criticism of the British Empire was necessary for the reappropriation of Roman heritage and Carthage served as the perfect other, the anti-Rome with which to link Britain. Nor was this process a cold blooded attempt by the regime to justify its imperialism, being rather the product of a relatively sophisticate intellectual discourse.

The fact that such a development emerged during a period where the veline still asked the press to be cautious shows the complexity of the relationship between the orders to the press and the actual evolution of the discourse in the worlds of politics and culture. The regime's appeals for restraint were mere attempts to moderate the exaggerated peaks of hostility by the everyday press, but they did not change the transformation of public discourse, which was becoming decidedly anti-British. The theme of the inferiority, or immorality, of British imperialism was of course to be continuously used during the Second World War in order to play down the idea that the conflict was a mere struggle between two different imperialisms. Pietro Cavallo described how books, pamphlets and even theatre performances emphasised this alleged fundamental difference. ${ }^{136}$ It would be beyond the scope of this work to enumerate all of these examples. What is interesting to underline is how, once again, the themes of war propaganda were not merely an expression of the need to slander the enemy; they were, instead, the logical evolution of a well-established, preexisting discourse that dated back many years before the war.

\section{The Traditional Friendship}

Another new, important theme that provides an example of the depth of hostility mounting in Italy against Britain was the systematic attack on the old notion of a 'traditional friendship' between the English and Italian peoples. Britain's contribution to the emergence of Italy as a unified nation state, while largely driven by self-interest, was difficult to deny. ${ }^{137}$ During the 1920 , the Fascist press had not attempted to undermine the idea that Britain had been a faithful friend 
of Italy since the Risorgimento, but they had not done much to celebrate it either, with articles appearing in Gerarchia describing in a quite neutral and pragmatic tone the conflict between the pro-and anti-Italian stances in Britain during the Italian unification. ${ }^{138}$

This changed during the second half of the 1930s. In 1936, the historian Carlo Morandi wrote that Britain had only pretended to be friendly in order to keep Italy a second-rate power. ${ }^{139}$ In November 1937, the ardently Fascist journalist Arnaldo Cervesato analysed in Gerarchia the history of Anglo-Italian relations during the Risorgimento, concluding that

English politics [... in the regards of Italy, has been characterised by a typical intransigence, to which the description of 'traditional' belongs much more than to a supposed 'friendship,' which existed, until today, only in the fantasy and the feelings of certain noble idealists and poets of the two countries. $^{140}$

The Fascist press emphasised the cold, implacable egoism of London. Conspiracy theories about Britain being the cause of the world's woes started to flourish at this time. The important Fascist journalist Alfredo Signoretti wrote that 'Albion's' attitude throughout the Ethiopian crisis had been a ploy to destroy the friendship between France and Italy. Had not divide at impera always been London's rule when it came to Europe ${ }^{141}$ However, optimism was common, for Britain had been defeated. Ugo D'Andrea, a Fascist intellectual close to Bottai, wrote that the defeat of Britain - whose empire was in crisis and whose fleet no longer ruled the seas - was an example of the more general agony of democracy. ${ }^{142}$ A few months later Curzio Villa, in his analysis of the British national character, wrote that the traditional friendship with Britain could not return, for the British people did not consider other peoples as their peers and did not understand reciprocity. ${ }^{143}$ Anti-British opinions among Italian patriots were carefully searched for and widely publicised. In 1940, Nevio Matteini reported Vincenzo Cuoco's harsh words against the British, who he described as 'enemies of all the peoples of the Earth.' Their egoism meant that any nation allied to London was doomed to be weakened by the deal, which would benefit only Britain. Far from being a friend of the Italian cause, Cuoco wrote, Britain was afraid of the growing threat Italy posed to its Mediterranean position. Mattei predictably commented that Cuoco's prophecy was finally becoming reality. ${ }^{144}$ In 1941, the journalist Alberto Consiglio considered a revisionist attitude regarding the 'traditional friendship' insufficient - it was important to underline how hypocritical Britain had been in the crucial years between 1799 
and I848. In a quick review of these years, he analysed the burning of the Neapolitan fleet by the British in 1799 ('the Neapolitan sea would never be reborn: this was, for British perfidy, an accomplishment'); Lord Bentinck's attempt to establish a British-esque parliament between 1806-1812 in Sicily; the attempts to detach Sicily from Naples in I8Is ('consequence: Italy could never become a Great Power, not even in the Mediterranean') and the support given to the Sicilian autonomists in 1848 , just to let the Neapolitans crush them ('London had, of course, given its warm moral solidarity'). Had London changed its attitude after I848? Consiglio concluded that the British had hoped that, given the Piedmontese' focus on the continent, the Italian naval tradition would be, if not choked, at least confined to the central Mediterranean. It was, according to Consiglio, the last mistake London would make regarding Mediterranean politics. ${ }^{145}$ In 1942, the journalist Carlo Fettarappa Sandri reached the conclusion that many other Fascist authors 'discovered' during the war years: Britain was the eternal enemy of Italy, in 1935-1936, in 1911-1912 (the Italian-Turkish war for Libya) and in the second Italian independence war in 1859 . This was demonstration of the 'traditional unfriendship' (tradizionale inimicizia) of the 'new Carthage against Rome."146

\section{The Victims of British Imperialism}

The British Empire was easy game for Fascist criticism. In 1935, Telesio Interlandi caustically wrote that there was indeed a large difference in terms of civilisation between the British and the Italian peoples. The Italians 'could never introduce civilisation in that [African] continent with the methods used by happily remembered General Roberts in Transvaal.' Attacking an editorial by a British newspaper about the supposedly poor Italian military record from the Battle of Adwa in 1896 to the Great War, Interlandi listed a number of shameful episodes in British colonial history, among which was the destruction of the beautiful Summer Palace in China in 1860 and the use of both hypocrisy and strength against the Boers. A few days later, the Star newspaper accused Interlandi's analysis of throwing 'mud on the map of Europe.' Interlandi replied that it was mud indeed, but 'made in England.' His further comment elucidates the deeper nature of Fascist indignation concerning British attitudes:

To investigate the history of the English Empire is certainly a nauseating task. It is not the violence that is disgusting, it is the cruelty dressed as humanitarism, masked with hypocrisy. A strong people can be violent, but must not be hypocritical. ${ }^{147}$ 


\section{Interlandi later added that}

of the so-called strong manners used by our English friends on the four corners of the globe to build their Empire we are not scandalised [...] we are scandalised by certain London newspapers' own scandal over Italian measures in Africa. ${ }^{148}$

The path was open and clear, for all the Fascist polemists had to do was to rejuvenate the old anti-colonialist tropes of D'Annunzio and early Fascism. The medieval historian Pier Fausto Palumbo, who in the future would join the antifascist resistance, celebrated the ancient ties between the Italian and Irish peoples, emphasising their common struggle against Britain and foreseeing that 'the end of the war, with the weakening that [it] will fatally cause to England, will make possible what could not be considered possible before September 1939, an Ireland that belongs truly, and forever, to the Irish.' ${ }^{149}$ In 1942, Cipriani denounced once again British crimes against Ireland, emphasising the racial differences between the two peoples. ${ }^{150}$ In 1942-1943, La Difesa della Razza, known for its rabid anti-Semitic and racist rhetoric, published a whole series of issues focused on Britain's cruel attitude towards its colonial subjects, as well as its national arrogance. The British past of piracy and slavery was a recurring theme. ${ }^{151}$ One article described the terrible conditions of the Black slaves taken from Africa by British cargoes. ${ }^{152}$

Indeed, what is remarkable regarding the tropes of anti-British propaganda after the beginning of the Second World War is that there was very little that was new in the criticism of Britain's treatment of its subjects. More generally, the aforementioned structural inferiority of British imperialism, the insistence on the supposed Jewish and Bolshevik control over the Foreign Office, as well as the extreme theories of La Difesa della Razza's racialists, were new elements. Yet many of the attacks focusing on British cruelty, hypocrisy and racism could have been written by authors belonging to the early Fascist period or by Fiume's Legionaries. When British imperialism in Africa was described as the most brutal form of exploitation, and the empire as a whole as the 'most monstrous form of plutocracy,' it was the same mixture of anticolonialist and antibourgeois themes so popular in the years between the end of the Great War and the Corfu crisis. Fascism itself, however, had changed. ${ }^{153}$ Its attempts to represent the Second World War as a war of the proletarian nations against the plutocracies had been overshadowed by the increasingly evident reality of the genocidal, racial war started by Germany, and the banner of Fascist anticolonialism had eventually collapsed under the contradictions that had characterised it since the beginning. ${ }^{154}$ For if the peculiar conditions of the Fiume experiment had meant 
that internationalism and anticolonialism could coexist with Italian nationalism, wartime Fascist Italy was effectively a ruthless colonial power, whose violent repression of its subjects was second to none of its colonial contemporaries.

If the Nazi perception of Britain as a world power was, as Gerwin Strobl argued, somewhat linear - at least before the war - the Fascist case is far more complicated. ${ }^{155}$ If the early Nazi movement was generally pro-British, early Fascism was quite the opposite. Unlike Hitler, who had always been an outspoken supporter of British imperialism and had always considered Britain a natural ally of a new, nationalistic Germany, at the end of the Great War Mussolini had quickly shifted from his wartime Anglophilia to a fierce criticism of London on nationalist grounds. Part of the reason was certainly that, unlike in Germany, there was no 'widespread admiration for Britain' after the war. Indeed, even during the conflict, Anglophobia was not unknown in Italy. Furthermore Mussolini, again unlike Hitler, did not feel any racial kinship with the British. If anything, he believed that the British thought very little of the 'Italian race.' Another reason was that many Italian Nationalists and Fascists considered Britain an obstacle to any future Italian expansion and were incensed by the role London had played in the peace treaties, whereas Hitler looked forward to an alliance with Britain against France and the Soviet Union. Mussolini's bitterness over Britain's attitude in the peace treaties led him to muse about the destruction of the British Empire by Italian hands, while the huge influence the Fiuman Republic's internationalist rhetoric had on early Fascism gave a clear anti-British attitude to the Fascist movement before the March on Rome in 1922.

Ennio di Nolfo wrote that, before the March on Rome, Mussolini had no foreign policy ideas of any sort. ${ }^{156}$ However, in terms of relations with Britain, between the end of the Great War and his seizure of power Mussolini was indeed gifted with a precise set of ideas regarding the situation and what had to be done about it. Britain was an enemy and an obstacle to Italy's path towards destiny, and as a consequence Italy had to threaten the British Empire by finding support abroad - ideas whose consistency with the eventual developments of Fascist foreign policy in the r 930 is striking.

Nor did this attitude disappear after Mussolini seized power. An analysis of the reactions of a not-yet-completely Fascistised press to the Corfu incident shows how pervasive Anglophobia remained among many Italians in 1923. At the same time, however, the extension, influence and tradition of government of the British Empire impressed a movement like Fascism, which considered strength the main force that ruled the world. In 1922, Margherita Sarfatti had written lyrically about the British Empire, comparing it to Rome, while other 
opinions had the chance to be heard during the second half of the 1920 , mostly because of the improvement in the relationship between the two countries. A relatively free range of opinions emerged, with the most consistent elements being the importance of the British Empire but also its decline. The perception of decline dramatically increased with the greater autonomy of Dominions like Canada and Australia around the beginning of the new decade, as well as the economic crisis that hit Britain hard. The press then started displaying a more aggressive attitude, remarking, if subtly, that Italy could take advantage of this new world in which Britain was no longer leading the way. The Ethiopian War unleashed a new wave of violent anti-British rhetoric, which was more a return to old themes than a creation of new ones. At this point, another remarkable difference with Nazi Germany emerged. If during the late 1930s many German National Socialists still considered British imperialism something to be emulated, after the Ethiopian War many Fascist intellectuals started to draw a clear line between Fascist 'Roman' imperialism and British 'Carthaginian' plutocracy.

The orders to the press hint that such a development was at least partially autonomous, for the orders themselves did not bother with details of the criticism and were more often than not used to restrain the attacks, trying to tune them with the necessities of the propaganda effort. An analysis of the orders during the Ethiopian campaign and after also suggest that this relatively restrained attitude from the regime might have been caused by confusion about the role Britain was playing, as well as uncertainty about the intentions of the Duce. On the other hand, it can be argued that if the regime tried again and again to restrain the press from attacking Britain, anti-British feeling was more widespread than is generally recognised. The newer 'systemic' criticism of the British Empire (which led to a reinterpretation of Britain as a power traditionally hostile to Italy) developed along with the more 'traditional' themes (anti-imperialism, proletarian nations against plutocracies.) It was, in Alan Cassel's words, 'in a perverted way [...] the same syndicalist revolutionary war preached by Mussolini in 1914-1915. ${ }^{.157}$ Such arguments had, however, lost much of their effectiveness since Fascist Italy had long relinquished, though not for lack of wanting, any credible role as a nonimperialist power. ${ }^{158}$

Admiration for the British Empire, nearly unanimous during the liberal period, was instead during the Fascist era shakier than previously thought. Grandi's positive remarks about the British Empire (he would soon change his mind, as we will see in chapter 4) represented only one of the many schools of thought about the 'health' of the British Empire and the character of the British people. Rather than universally recognising the strength of the empire, the image of 
decline registered by much of the Fascist discourse is reminiscent of the liberal one before the Great War. The later discourse proceeded to turn the British Empire into something inferior to both Roman and Fascist imperialism. Fascists used the Roman-ness myth in order to justify Italian supremacy in the Mediterranean, but Mussolini's Anglophobia, and that of Fascism more broadly, as well as the notion that Britain had to be challenged in the Mediterranean, did not just appear during the Ethiopian War and only resurface during the Second World War. It was instead something deeply rooted in the mythology and mindset of the Fascist movement first and later the regime. Systemic criticism of the British Empire was necessary to the reclaiming of Roman-ness.

Liberal admiration for the values and national characters inspiring the British Empire had waned by 1941, but the process of 'otherisation' of the British had not just been revived by the Second World War. ${ }^{159}$ It was instead the product of a discourse developed by Fascist intellectuals since before the Ethiopian War. Far from always being considered a model to emulate or compete with, British imperialism was increasingly framed as different and inferior, rather than as an admired rival. This reinforces the notion that anti-British discourse was not simply a card produced by the regime at times of political crisis, but had a 'life of its own.'

This also poses the necessity for nuance when discussing the category of modernity within Fascist discourse. As a general rule, modernity and industry were not at the core of Fascist critique of the British Empire; modernity was not incompatible with Romanità. Indeed, Romanità, as the historiography has underlined, was to be a living inspiration for the creation of the new Italians, a tool to forge a new Fascist modernity. In the words of Jan Nelis, antiquity was for the Fascists 'no faraway, dusty past, but a lively source of inspiration and energy, revealing the regime's modernist, revolutionary ambition to build a Third Rome. ${ }^{160}$ Rather than representing modern imperial power, it was instead Britain's alleged lack of the spiritualism, monumentality, eternity and universality that had been the trademark of Rome and were now central to Fascist modernity that the Fascists criticised.

This was an almost metaphysical interpretation of what made, according to the Fascist point of view, Roman and Fascist imperialism unique. In this sense, the Fascists did not need to reappropriate empire from the British, for London had always lacked the spiritual framework needed to be able to take the torch of empire and civilisation from Rome. The Fascist analysis of British imperialism cannot be correctly understood without taking into consideration the fact that Fascism considered itself the herald of a new civilisation, a radical alternative 
to the one represented by Britain, but not at all less modern. It was no rejection of modernity, nor the framing of Britain as modern (even if, as Cerasi argued, a commercial modernity) and hence un-Fascist, but indeed the opposite. ${ }^{161}$ It was rather that Britain had missed the bus of modernity (as understood by Fascist discourse) and was hence on the way to its decline. Furthermore, this idea was not a product of the Second World War nor of the '1930s Fascists.' Fascist view of British imperialism cannot be understood without understanding the Fascist view of modernity per se, a view that developed and triumphed within Fascist public discourse during the 1920s, long before the Ethiopian War. This is the subject of the next chapter. 